\title{
A retropharyngeal abscess caused by Francisella tularensis with an aberrant internal carotid artery on the same side
}

\author{
Francisella tularensisin neden olduğu retrofarengeal apse ve ayn tarafta \\ aberran internal karotis arter
}

Erbil Kılıç, ${ }^{1}$ Yusuf Hıdır, ${ }^{2}$ Yavuz Çekli, ${ }^{3}$ Turan Ilıca, ${ }^{4}$ Mustafa Gerek ${ }^{5}$

\author{
${ }^{1}$ Haydarpaşa Sultan Abdülhamid Ĕ̆itim ve Araştırma Hastanesi, Kulak Burun Boğaz Kliniği, İstanbul, Türkiye \\ ${ }^{2}$ Egepol Hastanesi, Kulak Burun Boğaz Bölümü, İzmir, Türkiye \\ ${ }^{3}$ Gülhane Eğitim ve Araştırma Hastanesi, Enfeksiyon Hastalıkları ve Klinik Mikrobiyoloji Anabilim Dalı, Ankara, Türkiye \\ ${ }^{4}$ MedicalPark Hastanesi, Radyoloji Bölümü, Ankara, Türkiye \\ ${ }^{5}$ Gülhane Ĕ̆itim ve Araştırma Hastanesi, Kulak Burun Boğaz Kliniği, Ankara, Türkiye
}

\begin{abstract}
Tularemia is a rare zoonotic disease caused by Francisella tularensis, which is a pathogenic spp. of Gram-negative, noncapsular, aerobic coccobacillus. Insect or rodent bite, contact with animals, consuming contaminated animal products, and water may be the routes of transmission. This bacterial infection has a significant place in the otolaryngology practice, as some patients with tularemia have signs and symptoms localized in the head and neck. In this article, we report a 60-year-old female patient with a four-month history of sore throat, dysphagia, right-sided neck mass, and fever. Radiological studies revealed a retropharyngeal abscess with a right-sided aberrant internal carotid artery. To the best of our knowledge, this is the first case of a retropharyngeal abscess caused by Francisella tularensis with an aberrant internal carotid artery on the same side.
\end{abstract}

Keywords: Aberrant carotid artery; Francisella tularensis; retropharyngeal abscess.

Francisella tularensis (F. tularensis) is an aerobic, noncapsulated, gram-negative coccobacillus. ${ }^{[1]}$ This bacteria is one of the most infectious pathogenic agents known, requiring inhalation or inoculation of as few as 10 microorganisms to initiate human infection. ${ }^{[2,3]}$ Two main types of $F$. tularensis have been described, F. tularensis tularensis (type A) which is only found in North America and highly virulent, $F$. tularensis holarctica (type B) which
$\ddot{O} Z$

Tularemi Gram-negatif, kapsülsüz, aerobik bir kokobasilin patojenik suşu olan Franciella tularensisin neden olduğu nadir görülen bir zoonozdur. Bulaş yolları böcek veya kemirgen ısırığı, hayvanlarla temas, hayvansal ürünlerin tüketilmesi ve suyla olabilmektedir. Tularemili hastaların bazılarında baş ve boyun yerleşimli bulgu ve belirtiler olduğu için, bu bakteriyel enfeksiyonun kulak, burun, boğaz uygulamasında önemli bir yeri vardır. Bu yazıda, dört aydır boğaz ağrısı, yutma güçlüğü, sağ taraflı boyun kitlesi ve ateş öyküsü olan 60 yaşında bir kadın olgu sunuldu. Radyolojik çalışmalarda, sağ taraflı aberan internal karotis arter ile birlikte retrofarengeal apse izlendi. Bilgimiz dahilinde, bu, aynı tarafta aberan internal karotis arter ile birlikte Francisella tularensisin neden olduğu ilk retrofarengeal apse olgusudur.

Anahtar sözcükler: Aberan karotis arter; Francisella tularensis; retrofarengeal apse.

is less virulent and found in the northern hemisphere. ${ }^{[4,5]}$ Human infection tends to occur generally in rural areas. ${ }^{[6]}$ The clinical picture may develop glandular, ulceroglandular, oculoglandular, oropharyngeal, pulmonary and septic forms, depending on the site of transmission. ${ }^{[5,7]}$ Tularemia is considered a potential threat as a biological weapon because of its virulence and the way of transmission as aerosolized droplets. ${ }^{[8,9]}$ 
After an incubation period of 3-5 days (range from 1 to 21 days), various clinical manifestations can arise from asymptomatic illness to fulminant toxemia with septic shock, but the most common clinical presentations are fever, sore throat, body aches, coryza, chills and rigor which of all are nonspecific. ${ }^{[10]}$ Fever and severe throat pain are the main symptoms of the oropharyngeal form (representing up to $12 \%$ of cases overall) that presents with pharyngitis or tonsillitis with oral ulcers and unilateral cervical, preauricular and retropharyngeal lymphadenopathy. ${ }^{[11-14]}$ This form can be acquired by exposure to contaminated water or consumption of poorly cooked meat. ${ }^{[15]}$ Glandular tularemia involves lymphadenopathy, generally cervical in the deep jugular chain without an identifiable skin lesion and $42 \%$ of cases feature high fever associated with bradycardia (pulse-temperature dissociation). ${ }^{[10,16]}$

Here, we present a case of tularaemia that caused a retropharyngeal abscess on the same side as an aberrant internal carotid artery.

\section{CASE REPORT}

A 60-year-old woman who had type 2 diabetes mellitus and hypertension was admitted to a community hospital with symptoms of fever, chills, sore throat and malaise. Her symptoms persisted despite therapy with several oral antibiotics. After one month, she reported a rightsided upper cervical swelling and dysphagia and received parenteral ceftriaxone $1 \mathrm{gr}$. three times per day and ciprofloxacin $400 \mathrm{mg}$ two times per day. After parenteral antibiotic therapy, her temperature normalized but cervical swelling and dysphagia persisted.

Approximately two months after her symptoms started, she was transferred to our clinic. Physical examination demonstrated a $4 \times 2 \mathrm{~cm}$, semisolid, fixed right upper cervical mass. On oral examination and fiberoptic upper airway endoscopy a giant bulge was seen extending from the posterolateral nasopharynx to the epiglottis, medializing the right tonsil and arytenoids (Figure 1). Her white blood cell (WBC) count was $7370 / \mathrm{mm}^{3}$ and erythrocyte sedimentation rate (ESR) was $58 \mathrm{~mm} / \mathrm{h}$. Serum electrolytes and liver and kidney function tests were normal. Ultrasonography of neck revealed a 40×20 mm, multicystic, necrotic lymphadenopathy in the right cervical jugulodigastric region. Magnetic resonance imaging (MRI) and contrast enhanced computed tomography (CT) identified submandibular and upper cervical necrotic lymphadenopathy (Figure 2) and also a 30x10 mm fluid collection extending in the retropharyngeal space from the level of the second cervical vertebrae (C2) and inferior part of the nasopharynx to the ventral side of the longus capitis muscle (Figure 3). Contrastenhanced MRI demonstrated ring-shaped opacification around the collection and these scans were similar to the retropharyngeal abscess. Magnetic resonance and contrast enhanced CT imaging also revealed the abnormal course of the right internal carotid artery (ICA) corresponding to the retropharyngeal space at the level of the nasopharynx and oropharynx; this abnormal course of the ICA had been considered a continuation of the abscess during fiberoptic upper airway endoscopy. (Figure 2, 4). Francisella agglutination test yielded a positive result (1/640).

The patient received doxycycline $100 \mathrm{mg}$ two times per day and streptomycin $1 \mathrm{gr}$ one times per day and enlarged, necrotic cervical lymph nodes were aspirated and aspirates analyzed microbiologically. Since microbiological cultures were negative, the patient was taken to the operating room. During surgery, a multilocular, thick-walled, abscessed lymph node and retropharyngeal abscess was drained. After surgery, all of her symptoms resolved completely in a week. She received doxycycline for three weeks and streptomycin for two weeks. Written informed consent was obtained from the patient to report this case.

\section{DISCUSSION}

Consumption of contaminated food and uncontrolled spring water are considered to be the main mode of transmission of $F$. tularensis in Turkey. ${ }^{[17,18]}$ The oropharyngeal type is more common in Turkey although the ulceroglandular type is the most common type of

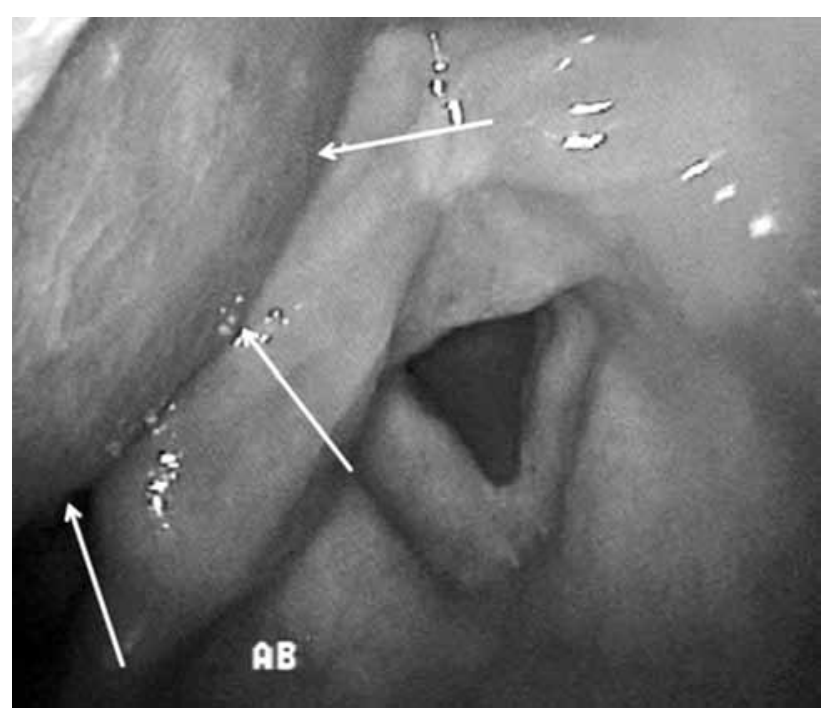

Figure 1. A giant bulge extending from the posterolateral nasopharynx to the epiglottis, medializing the right tonsil and arytenoids. 


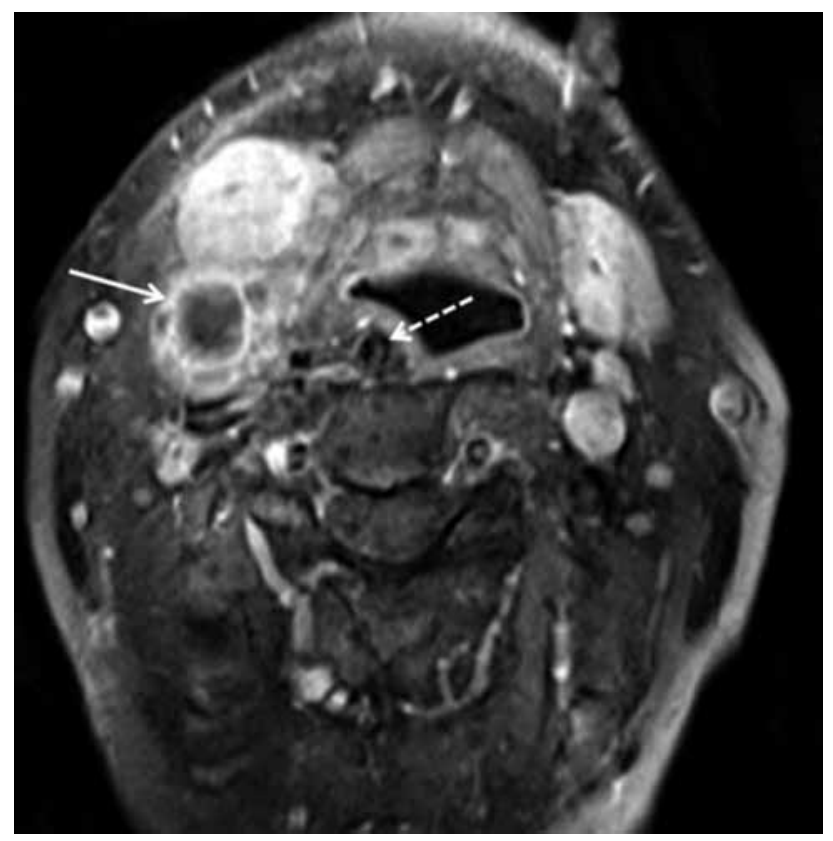

Figure 2. Axial magnetic resonance imaging showing submandibular and upper cervical necrotic lymphadenopathy with aberrant internal carotid artery on the same side.

tularemia in the literature. ${ }^{[11,17]}$ Approximately $85 \%$ of patients have enlarged lymph nodes, especially in the cervical and periauricular region and these enlarged lymph nodes are the only clinical sign in $50 \%$ of patients with $F$. tularensis. ${ }^{[19,20]}$

Based on duration, cervical lymphadenopathy is classified into three groups; acute lymphadenopathy (less than 2 weeks), subacute lymphadenopathy

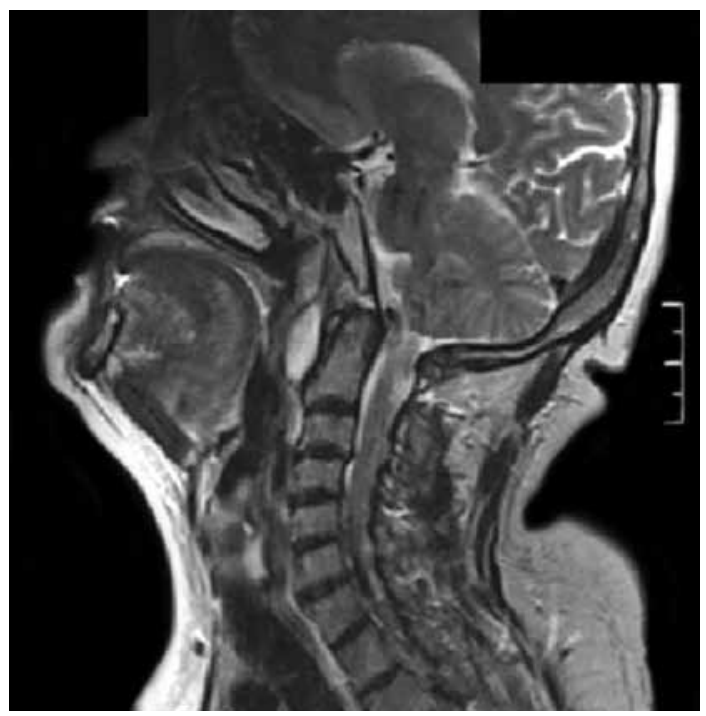

Figure 3. Sagittal magnetic resonance imaging showing retropharengeal abscess.

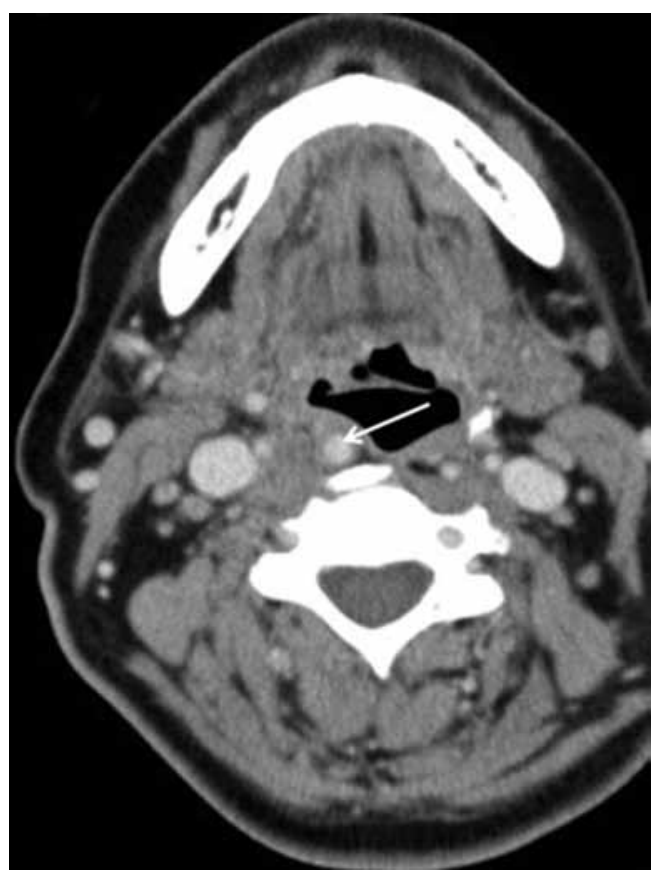

Figure 4. Contrast enhanced computed tomography showing aberrant internal carotid artery.

(2-6 weeks), chronic lymphadenopathy (more than 6 weeks). ${ }^{[21]}$ Tuberculosis, Hodgkin disease, nonHodgkin lymphoma, leukemia, HIV infection, KikuchiFujimato disease, cat-scratch disease, toxoplasmosis and tularemia are considered in the differential diagnosis of chronic cervical lymphadenopathy. ${ }^{[22,23]}$ These diseases can mimic each other. Serology, neck and chest imaging, fine needle aspiration biopsy, history of the patient (living in an endemic-zone, history of exposure, presence of skin lesions) and excisional biopsy are used to identify the etiology of chronic cervical lymphadenopathy.

Considering the difficulty of identifying $F$. tularensis by routine microbiological screening protocols, the diagnosis of $F$. tularensis is based upon clinical suspicion. Serology (tube agglutination and microagglutination) is the main process of diagnosing $F$. tularensis microbiologically since the culture and isolation of the bacterium is difficult and hazardous. ${ }^{[24]}$ Enzyme linked immunosorbent assay (ELISA) is another, safer way of diagnosing this bacteria. ${ }^{[20]}$ Routine laboratory test results and white blood cell count are also nonspecific in diagnosis and histopathological evaluation does not provide pathognomonic signs for tularemia. ${ }^{[6]}$

Abscess formation in a single or multiloculated appearance, enlarged lymph nodes with or without central necrosis and peripheral enhancement following intravenous (IV) contrast media administration were 
reported as the $\mathrm{CT}$ findings of tularemia cases with neck abscess. ${ }^{[25]}$ Ugur et al. ${ }^{[6]}$ described the MRI findings of two cases with tularemia, wherein cystic lesions located on the medial part of the sternocleidomastoid muscle with peripheral enhancement and irregular borders consistent with abscess formation were detected on MRI. Therefore, tularemia must be kept in mind in the differential diagnosis of necrotizing lymphadenitis of the neck.

For the treatment of all forms of tularemia, the drug of first choice is streptomycin. ${ }^{[20]}$ Gentamycin is also another effective antibiotic but macrolides, betalactams, trimoxazole and lincosamides are not preferred. ${ }^{[21]}$ Ciprofloxacin, doxycycline and chloramphenicol have also been demonstrated to be effective. The therapy must be given at least for 7-14 days. In the presence of a fluctuant abscess or large lymphadenopathy, surgery is needed. ${ }^{[8,13]}$ Vaccination is recommended only for laboratory personnel who routinely work with this organism since it provides only incomplete protection. ${ }^{[10]}$

An aberrant carotid artery is a very rare variation with an incidence of about $5 \%$ in the general population. ${ }^{[27]}$ This variation of ICA (angulation) is divided into two categories: kinking and tortuosity. ${ }^{[28]}$ The sharp bend of ICA is called kinking and undulation, elongation, redundancy and S-shaped curve are called tortuosity. ${ }^{[29]}$ Aberrant carotid artery may cause fatal complications during routine otolaryngology procedures such as tonsillectomy, peritonsillar and retropharyngeal abscess drainage, biopsy and pharyngoplasty. In all oral lesions, caution should be taken especially when there is a palpable pulsation or bruit to prevent massive bleeding.

In conclusion, it is not impossible for a patient to have infrequent clinical presentations and rare anatomical variations at the same time as we report in this article. F. tularensis may cause, retropharyngeal, peritonsillar and parapharyngeal abscess, and vascular variations must be considered in all oral masses. Contrast enhanced CT and possibly, MRI should be performed before a surgical procedure in such cases.

\section{Declaration of conflicting interests}

The authors declared no conflicts of interest with respect to the authorship and/or publication of this article.

\section{Funding}

The authors received no financial support for the research and/or authorship of this article.

\section{REFERENCES}

1. Tärnvik A, Berglund L. Tularaemia. Eur Respir J 2003;21:361-73.
2. Dennis DT, Inglesby TV, Henderson DA, Bartlett JG, Ascher MS, Eitzen E, et al. Tularemia as a biological weapon: medical and public health management. JAMA 2001;285:2763-73.

3. Evans ME, Gregory DW, Schaffner W, McGee ZA. Tularemia: a 30-year experience with 88 cases. Medicine (Baltimore) 1985;64:251-69.

4. Ellis J, Oyston PC, Green M, Titball RW. Tularemia. Clin Microbiol Rev 2002;15:631-46.

5. Schmid GP, Kornblatt AN, Connors CA, Patton C, Carney J, Hobbs J, et al. Clinically mild tularemia associated with tick-borne Francisella tularensis. J Infect Dis 1983;148:63-7.

6. Ugur KS, Ark N, Kilic S, Kurtaran H, Kosehan D, Gunduz M. Three cases of oropharyngeal tularemia in Turkey. Auris Nasus Larynx 2011;38:532-7.

7. Penn RL. Francisella tularensis (Tularemia). In: Mandell GL, Bennett JE, Dolin R, editors. Principles and practice of infectious diseases. Philadelphia: Elsevier-Churchill Livingstone; 2005. p. 2674-85.

8. Stupak HD, Scheuller MC, Schindler DN, Ellison DE. Tularemia of the head and neck: a possible sign of bioterrorism. Ear Nose Throat J 2003;82:263-5.

9. Cronquist SD. Tularemia: the disease and the weapon. Dermatol Clin 2004;22:313-20.

10. Collison PJ, Adams B. Glandular tularemia in a Native American child. Ear Nose Throat J 2003;82:851-4.

11. Helvaci S, Gedikoğlu S, Akalin H, Oral HB. Tularemia in Bursa, Turkey: 205 cases in ten years. Eur J Epidemiol 2000;16:271-6.

12. Arikan OK, Koç C, Bozdoğan O. Tularemia presenting as tonsillopharyngitis and cervical lymphadenitis: a case report and review of the literature. Eur Arch Otorhinolaryngol 2003;260:298-300.

13. Atmaca S, Bayraktar C, Cengel S, Koyuncu M. Tularemia is becoming increasingly important as a differential diagnosis in suspicious neck masses: experience in Turkey. Eur Arch Otorhinolaryngol 2009;266:1595-8.

14. Dlugaiczyk J, Harrer T, Zwerina J, Traxdorf M, Schwarz $\mathrm{S}$, Splettstoesser W, et al. Oropharyngeal tularemia--a differential diagnosis of tonsillopharyngitis and cervical lymphadenitis. Wien Klin Wochenschr 2010;122:110-4.

15. Luotonen L, Tapiainen $\mathrm{T}$, Kallioinen M, Luotonen J. Tularemia of the middle ear. Pediatr Infect Dis J 2002;21:264-5.

16. Patt HA, Feigin RD. Diagnosis and management of suspected cases of bioterrorism: a pediatric perspective. Pediatrics 2002;109:685-92.

17. Akalin H, Helvaci S, Gedikoğlu S. Re-emergence of tularemia in Turkey. Int J Infect Dis 2009;13:547-51.

18. Leblebicioglu H, Esen S, Turan D, Tanyeri Y, Karadenizli A, Ziyagil F, et al. Outbreak of tularemia: a case-control study and environmental investigation in Turkey. Int J Infect Dis 2008;12:265-9.

19. Tunga U, Bodrumlu E, Acikgoz A, Acikgoz G. A case of tularemia presenting as a dental abscess: case report. Oral Surg Oral Med Oral Pathol Oral Radiol Endod 2007;103:33-5. 
20. Gallego L, Junquera L, Palacios JJ, de Vicente JC. Cervical tularaemia in a non-endemic area. Med Oral Patol Oral Cir Bucal 2009;14:180-2.

21. Allhiser JN, McKnight TA, Shank JC. Lymphadenopathy in a family practice. J Fam Pract 1981;12:27-32.

22. Ferrer R. Lymphadenopathy: differential diagnosis and evaluation. Am Fam Physician. 1998;58:1313-20.

23. Na DG, Lim HK, Byun HS, Kim HD, Ko YH, Baek JH. Differential diagnosis of cervical lymphadenopathy: usefulness of color Doppler sonography. AJR Am J Roentgenol 1997;168:1311-6.

24. Guffey MB, Dalzell A, Kelly DR, Cassady KA. Ulceroglandular tularemia in a nonendemic area. South Med J 2007;100:304-8.

25. Oztoprak N, Celebi G, Hekimoglu K, Kalaycioglu B.
Evaluation of cervical computed tomography findings in oropharyngeal tularaemia. Scand J Infect Dis 2008;40:811-4.

26. Cağlı S, Vural A, Sönmez O, Yüce I, Güney E. Tularemia: a rare cause of neck mass, evaluation of 33 patients. Eur Arch Otorhinolaryngol 2011;268:1699-704.

27. Lo CC, Luo CM, Fang TJ. Aberrant internal carotid artery in the mouth mimicking peritonsillar abscess. Am J Emerg Med 2010;28:259.

28. Leipzig TJ, Dohrmann GJ. The tortuous or kinked carotid artery: pathogenesis and clinical considerations. A historical review. Surg Neurol 1986;25:478-86.

29. Prokopakis EP, Bourolias CA, Bizaki AJ, Karampekios SK, Velegrakis GA, Bizakis JG. Ectopic internal carotid artery presenting as an oropharyngeal mass. Head Face Med 2008;4:20. 